\title{
Miranda
}

Revue pluridisciplinaire du monde anglophone /

Multidisciplinary peer-reviewed journal on the English-

speaking world

$12 \mid 2016$

Mapping gender. Old images ; new figures

\section{"The Lucid Body": Training Method for Actors. Getting Personal with Fay Simpson}

Interview with Fay Simpson

\section{Céline Nogueira}

\section{(2) OpenEdition}

\section{Journals}

\section{Electronic version}

URL: http://journals.openedition.org/miranda/8348

DOI: $10.4000 /$ miranda.8348

ISSN: 2108-6559

\section{Publisher}

Université Toulouse - Jean Jaurès

\section{Electronic reference}

Céline Nogueira, "'The Lucid Body": Training Method for Actors. Getting Personal with Fay Simpson", Miranda [Online], 12 | 2016, Online since 29 February 2016, connection on 16 February 2021. URL: http://journals.openedition.org/miranda/8348 ; DOI: https://doi.org/10.4000/miranda.8348

This text was automatically generated on 16 February 2021

\section{(c) $($ ) $\odot \odot$}

Miranda is licensed under a Creative Commons Attribution-NonCommercial-NoDerivatives 4.0 International License. 


\title{
"The Lucid Body": Training Method for Actors. Getting Personal with Fay Simpson
}

\author{
Interview with Fay Simpson
}

Céline Nogueira

The Lucid Body: Website

http://lucidbody.com/ 


\section{[FIgURE 1]}

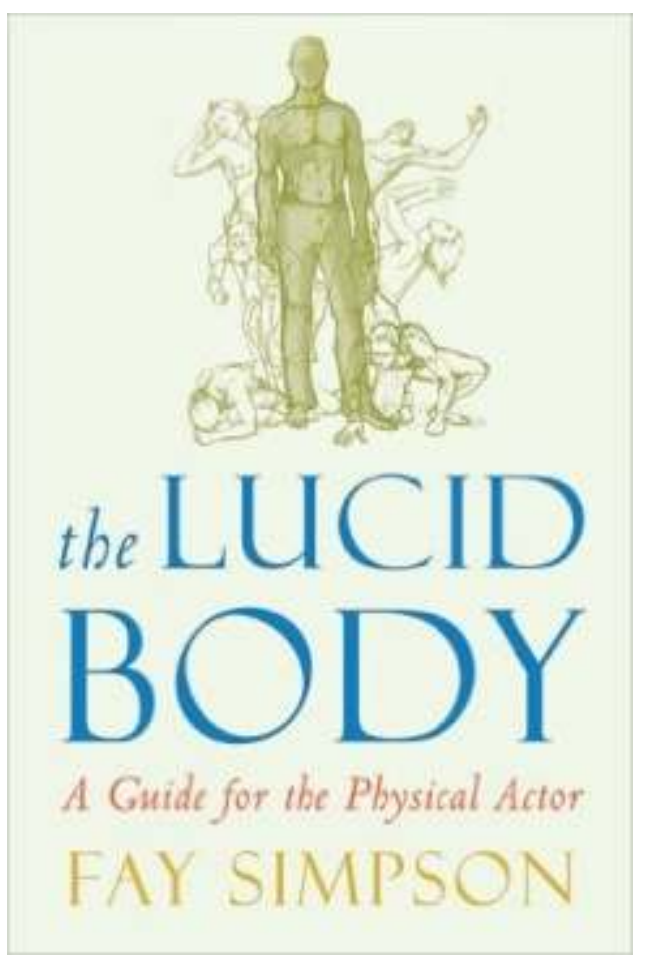

Simpson, Fay. The Lucid Body: A Guide for the Physical Actor. New York: Allworth Press, 2008.

Credits : Cover design by Mary Belibasakis; cover illustruation by Eleanor Boynton

\section{Biography of the Interviewee:}

\section{Fay Simpson}

Associate Arts Professor at NYU's Graduate Acting Program (Movement), Founder of The Lucid Body; a process of physical acting

Fay Simpson has been the Artistic Director and co-founder of Impact Theatre since its creation in 1990. Informed by her work in the rehearsal room, the teaching studio and onstage over the last 20 years, Ms. Simpson has developed a unique physical training method for the actor called "The Lucid Body". She has taught at The Yale School of Drama, the New School's Eugene Lang, Michael Howard Studios, The Studio/NY, Marymount Manhattan College, and at the Actor's Center. She runs private classes and workshops at her own studio The Lucid Body House in midtown Manhattan, as well as in Berlin and London.

She coaches for film and TV as well as stage (Lupita Nyong'o in 12 Years A Slave and in Eclipsed soon to be on Broadway; Annaleigh Ashford in Sylvia with Mathew Broderick currently on Broadway; Amanda Warren The Leftovers on HBO in 2014.

Fay wrote The Lucid Body; A Guide for the Physical Actor, published in 2008 by Allworth Press. She has trained seven teachers who now teach the Lucid Body in Texas, New York, London, Berlin and Moscow. The next Lucid Body Teacher Training program starts in 2016. www.lucidbody.com 


\section{Theatre for Social Change:}

In the summer of 2011, Fay developed and taught a graduate course with Yale Drama and Divinity graduate students in Tanzania called Catalysts for Social Change, with Gamal Palmer. Along with Mgunga Mwa Myyenyelwa, from Parapanda Arts Lab, she codirected street pieces in marginalized communities to engender community dialogue. She learned the Behavior Change Process from Mgunga, which she is now employing in her Veterans Project; Homecoming, which she brings to VA centers around NY to stimulate dialogue and change.

Fellowships:

8 2013, Fay received a Fellowship from the Likhachev Foundation in St. Petersburg, Russia, where she studied the Master teachers at the St. Petersburg Academy, followed by a teaching tour in Moscow, Berlin, London and Paris.

2008, Ms. Simpson is the recipient of the 'Amy and Eric Berger National Theatre Essay Award' for development of her book, The Lucid Body; A Guide for the Physical Actor. This book was hailed by Drama Book Shop as "one of the ten most essential books for the actor."

2000, solo performance piece entitled Trapped In Seven, for which she was honored with "Best Female Performer" in the Spotlight On awards of 2000.

1999, Ms. Simpson was awarded a Fox Foundation Fellowship, which enabled her to serve as an Assistant at the New Globe Theatre in London under the artistic directorship of Mark Rylance for the 1999 - 2000.

1996, She was awarded a Tennessee Williams Fellowship from The University of the South, Sewanee

\section{Theater Companies that have hired Fay as movement coach in the} US:

13 Terra Firma (Cries and Whispers), Scandinavian American Theatre Company (Miss Julie), Karin Coonrad ("Everything that Rises Must Converge")

14 Internationally: Toulouse, France with Innocentia Inviolata (Of Kings and Men), London with Gabrielle Moleta (The Outsiders), Dar es Salaam, Tanzania with Parapanda Arts Lab.

\section{Impact Theatre:}

15 Ms. Simpson conceived, directed and produced several original physical theatre productions at Manhattan Class Company: D-Train, Take Me Home, Degas' Little Dancer, and Research \& Development. Other Off-Broadway and International productions include Raging Womenand One Bad Man, Kurt's Wife: A Story of Lotte Lenya, The Marital Bliss of Francis \& Maxine, Better, Triptych, and two solo performance piece entitled Trapped In Seven and Grey Gone. She is currently working on a new piece, SCOTTY, as an artist in residence at Stella Adler Studio of Acting. This original physical theatre piece is inspired by the Raymond Carver short story, A Small Good Thing.

16 Fay Simpson received her B.F.A. in Theatre \& Dance from Colorado College and her M.A. from NYU's Gallatin School. She is a member of the Actor's Center. 


\section{The Interview}

Céline Nogueira: I have known Fay for nearly 14 years. We met at the Stella Adler Studio in New York. Fay choreographed King Lear directed by Joseph Siravo; I played the part of The Fool with Dir. Joseph Siravo and I was The Fool. Later as a professional actress, I got to play the Femme Fatale in her Off-Broadway piece Tryptich-Juicing the Fruit and then learned the "Lucid Body" basics with Fay. Years later, back in Toulouse, I invited Fay to the Theatre Garonne (Toulouse, France) to co-direct with me Of Kings and Men a piece about men in power and the role of women, using texts from Shakespeare. Her book, The Lucid Body: A Guide For the Physical Actor, was published in 2008, and while it is being translated in German, Fay has entrusted me with the translation into French. In 2016, she is our distinguished guest for the first edition of "American Theatre Project" in Toulouse coming this forthcoming May and June. From her softness to her ferocious drive, what strikes me in Fay is her working endurance together with her contagious urge to move forward and smile. Beyond the pleasure and nurturing experiences that I have shared with her, I can easily say that she is a source of inspiration when it comes to getting over the harshness of work, of life and constantly redefining oneself as human being. Because of her qualities as a choreographer, director, teacher, woman, it is no wonder that we, Emeline Jouve and I cofounders of the American Theatre Project, wanted to introduce you to Fay Simpson.

Céline Nogueira: Who are you?

Fay Simpson: I am the founder of "The Lucid Body", Artistic Director of Impact Theatre, and an Associate Arts Professor at Tisch School of the Arts; NYU Grad Acting.

$\mathrm{CN}$ : What is "The Lucid Body"? What are the missions of The Lucid Body House? Where are you at and what is left to be done? While undertaking the task of transmitting the "Lucid Body" in New York and throughout the world, what were/are the main obstacles?

Fay Simpson: Our mission is to offer a holistic form of acting training. This is happening all over the world now. So I want to make sure I have teachers in all the important cities, which is why I want YOU to get your certification. The Lucid Body House is a home for like minded theatre practitioners who are working with creativity as a way of healing the self and the world. God knows we need work that gives us faith in the human spirit, because these times are dark. There always has to be those of us with faith in the ultimate goodness of humans.

$\mathrm{CN}$ : According to you, what is the main difference between directing a play, or a show, and teaching?

Fay Simpson: Directing a play is much more indulgent. It is about what I want to see. It is me painting a picture on the stage, the colors being my actors. When I teach, it is not about me at all. It is about the students and what they need to move forward in their integration process.

$\mathrm{CN}$ : How would you describe your writing process in the writing of your book The Lucid Body: A Guide for the Physical Actor?

Fay Simpson: I did the hard work at the Gallatin School, NYU, while writing my thesis. They led me through a very organized process of setting up the right questions, and researching the field in every way. The book happened after I graduated. I took the thesis and made it personal. I thought the last thing I wanted to write was another DRY, technical movement book. I wanted the book to be a good read. And the closer to the bone, the more universal. 
$\mathrm{CN}$ : I feel that The Lucid Body is a book on acceptance. Accepting our self. Accepting the Other. Accepting-by reaching our own limits-our infinite and incredible potential. What do you think?

Fay Simpson: The Lucid Body is about accepting your human condition with all its complexity. Being present with what is actually going on within yourself is hard. Our minds try to tell us what we SHOULD be feeling and what we SHOULD be producing. But our body and being might actually be experiencing something quite different. The more we accept say, our insecurity, really feel it and smell it, the more we will accept it in others. The Lucid Body is about compassion for others and for yourself. You can't play another character if you judge that character. You have to have the human understanding of that character's choices. That is the goal of this process.

$\mathrm{CN}$ : Can you share an event, one that could be labelled as "negative", that happened in your life and that you can say for sure that it built who you are now. And how did it build you?

Fay Simpson: When I was diagnosed with an auto-immune disease in the late 80's, I became very focused on how to improve my immune system, by looking at my psycho-physical health. I left my marriage, I started choreographing using all the emotions that I felt were trapped in my body, clogging my system. My sense was that perfect flow in the body, blood flow, emotional flow, chakra flow, air flow, would allow for ultimate immune care. It turns out that I got a job teaching actors at this time, and hence was The Lucid Body born. And my immune system recovered.

$\mathrm{CN}$ : Can you share an event, one that could be labelled as "positive", that happened in your life and that you can say for sure that it built who you are now. And how did it build you?

Fay Simpson: Of course I have many positive experiences. One was Michael Howard giving me this open door to teach... teach what I felt was true. I did not know how to teach, so that was a big trust on his part. I was at his studio developing the Lucid Body for 15 years.

The other event that must be spoken is the birth of my child. Being a mother and raising a child shifted my understanding of life so profoundly, that I am sure I became a better teacher, director and mentor. The depth and complexity of emotions that I experienced towards my daughter, changed my understanding of myself. Grief was entirely different, joy was unfathomable, fear was inescapable. To this day... it is just organic. And I feel blessed to have been able to be both a mother and an artist. It is a very difficult combination in terms of finances, but wonderful in terms of depth of expression.

CN: I have known you for... 14 years now. I see you as a gentle and free woman. A courageous one and a tenacious business woman. A Generous collaborator. What could we add?

Fay Simpson: I have become a committed teacher. I think that they say 10,000 hours of doing something creates a master. Well, I don't know if I am a master, but I have certainly put the hours in. When I walk in a classroom, something bigger than me happens. I focus on process and seeing deeply where each individual is. I guess I have found my calling.

$\mathrm{CN}$ : It is no secret that building a career is immensely hard for women. I also see how at times women in the professional areas, take over what we'd call men's behavior-bully, competition orientated, emotionless-and thus lose themselves, their creative femininity, 
their specific emotive and sensorial intelligence. We have often talked about these issues along with the degree of acceptance of one's own body for example.

I can see how our patriarch system/society has molded a majority of women into becoming aliens to their own selves-that is a creature to best fit men. Sexist ads are a good example of how women are supposed to dress and eat and behave in a certain waythe way men like. And I also see how some women feel suspicious about their fellow women, as if they feared, in anticipation, the competition which is actually put inside of them by men. So we see how they have developed this competitive behavior as a survival instinct-survive in the eyes of men, and, in turn, survive as the chosen female who will be able to procreate.

So, these women who tend to develop that feeling of suspicion do so because they accept to be looked at from the unique perspective of men, to become the best fit, and thus are constantly comparing themselves with the other women who have naturally become rivals, competitors.

Sometimes, while i am naturally expecting sorority, I stumble upon suspicion and the kind of distortion I have just described. And while i see these women becoming emotionless and stern, yet they are yearning to get their own nature back.

Never have I felt that in you or from you. Communicating with you is free of that masculine influence. This masculine/feminine aspect is actually balanced. How do you think that happened? Did you have to work on it and how? For me, maternity and the awareness of violence done unto women is how I came to realize how women needed sorority and that is when I started to observe this "survival thing" in women. How was it for you?

Fay Simpson: This has been a very big topic in my life. I grew up with a sister who was barely a year older. We were called "the girls" and there was naturally a competition between us. She was older, bigger, smarter in every way, so maybe the competition was just on my part, but it started to eat me alive. Then when I was a dancer, oh my God, women were ruthless with their back biting and dueling for the better roles. So I took a hard U turn by starting a Buddhist practice and psycho-therapy and frankly, by having a female lover. By loving another woman, my whole perspective changed. Instead of competing with them, I would notice their beauty and their gifts. Ah, what a relief to live life in collusion with other women. I did a piece called Ancient Women, comparing the modern woman tendency to compete (like men) and isolate, with the women in the ancient societies, who were a unit, sharing their red tents, and their rituals and medicines around birthing and dying. This piece (I can't find this in a day, so I will just describe it), was an image of women working together, then quick cut to women back biting and nasty to each other in the contemporary world ... it went back and forth like this. Actually the piece you were in, Juicing The Fruit, was similar. It was about women trying to be more desirable in the eyes of men, to the exclusion of each other. It is a big topic for me, as I said. When other women compete with me, I find it insulting and un-friendly. I move away very quickly. That is why I like working with you. That has never been an issue between us.

$\mathrm{CN}$ : What is the biggest challenge, issue, obstacle, joy in working with women?

Fay Simpson: I think I have answered this in the last question. Women, when collaborating with open hearts and open second chakras, are a dream, like a river flowing. When egos get in the way, it can create an environment cold as ice.

$\mathrm{CN}$ : Who/what are you inspired by?

Fay Simpson: I am inspired by passionate art that reaches me to the bone. Recently, I saw Antigone created by Noche Flamenco... it rocked my soul. I am inspired by 
individuals who live their lives according to their curiosity, not according to social pressure and fashion. I am always inspired by a heavy rain-storm.

$\mathrm{CN}$ : I always ask my students "since the last time we saw each other, what have you learned?"

Fay Simpson: That the more you know, the more you don't know. I feel more fragile, and more shy than I ever have before. When the layers of protection start to peel away, what are we left with? Maybe one day I will just disappear.

$\mathrm{CN}$ : Since the last time we saw each other, what has caught your attention?

Fay Simpson: I want to learn Sign Language.

$\mathrm{CN}$ : Thank so much Fay for your time and generosity!

\section{ABSTRACTS}

Interview with Fay Simpson, founder of the Lucid Body, a technique for physical actors, which uses the energetic chakra centers. The interview was conducted by emails in December 2015.

Entretien avec Fay Simpson, fondatrice du "Lucid Body» (le corps lucide), méthode d'accompagnement de l'acteur physique qui fait appel aux centres d'énergie, chakras. L'entretien, réalisé en décembre 2015, consistait en un échange de courriels et conversations téléphoniques.

\section{INDEX}

Subjects: Theater

Mots-clés: théâtre américain, interprétation, danse, femmes, carrière, New York, International, Lucid Body, technique, méthode, chakras, Triptych, Juicing the fruit, Impact Theatre, American Theatre Project

Keywords: American Theatre, acting, dance, women, career, New York, International, Lucid Body, method, chakras, Triptych, Juicing the fruit, Impact Theatre, American Theatre Project

\section{AUTHOR}

\section{CÉLINE NOGUEIRA}

Innocentia Inviolata Theatre Company/Conservatory of Dramatic Arts, Toulouse Artistic Director, Teacher, Translator and Writer celine.nogueira@gmail.com 